\title{
Enhancement of Mathematics Critical Thinking Skills through Problem Based Learning Assisted with Concrete Media
}

\author{
Ni Pt Dyah Pramestika \\ Primary School Teacher Education Study Program, FIP, Ganesha University of Education, Singaraja, Indonesia \\ Email: dyahpramestika@gmail.com
}

I. Gst Ag Ayu Wulandari

Primary School Teacher Education Study Program, FIP, Ganesha University of Education, Singaraja, Indonesia

Email: ayu.wulandari@undiksha.ac.id

I W. Sujana
Primary School Teacher Education Study Program, FIP, Ganesha University of Education, Singaraja, Indonesia Email: iwayan.sujana@undiksha.ac.id

\section{A R T I C L E I N F O \\ Article history: \\ 1 Mei 2020 Received in revised form \\ 11 Juni 2020 \\ Accepted 10 Juli 2020 \\ Available online 25 Agustus \\ 2020 \\ Kata Kunci: \\ Problem Based Learning, \\ Konkret, Kritis \\ Keywords: \\ Problem Based Learning, \\ Concrete, Critical}

\begin{abstract}
A B S T R A K
Pada pembelajaran matematika masih ditemukan siswa susah memahami dan kurang mengembangkan kemampuan berpikir kritis. Oleh karena itu, tujuan penelitian ini untuk mengetahui pengaruh yang signifikan model Problem Based Learning berbantuan media konkret terhadap kemampuan berpikir kritis matematika pada kelas IV di SD. Penelitian ini adalah penelitian eksperimen semu dengan desain non-equivalent control group design. Populasi penelitian ini adalah kelas IV SD sebanyak 293 orang. Sampel penelitian ini ditentukan dengan teknik cluster random sampling. Sampel pada kelompok kelompok eksperimen sebanyak 32 siswa dan kelompok kontrol sebanyak 30 siswa. Pengumpulan data yang digunakan adalah metode tes berupa tes subjektif (uraian). Data yang diperoleh dianalisis menggunakan teknik analisis uji-t dengan rumus polled varians. Hasil anlisis data diperoleh (thitung $=4,021>$ tabel $=2,000)$ pada taraf signifikasi $5 \%(\mathrm{dk}=32+30-2=$ 67) yang berarti terdapat perbedaan yang signifikan kemampuan berpikir kritis matematika antara kelompok yang dibelajarkan dengan model Problem Based Learning berbantuan media konkret dengan kelompok yang dibelajarkan menggunakan model pembelajaran konvensional pada kelas IV SD. Hasil penelitian ini dapat digunakan sebagai bahan masukan bagi guru untuk memilih model pembelajaran yang bervariasi dalam mengajar.
\end{abstract}

\begin{abstract}
A B S T R A C T
In learning mathematics, students are still found to have difficulty in understanding and developing critical thinking skills. Therefore, the purpose of this study is to determine the significant influence of the Problem Based Learning model assisted by concrete media on the ability to think critically mathematics in grade IV in elementary school. This research was a quasiexperimental study with a non-equivalent control group design. The population of class IV SD as many as 293 people. The sample was determined by cluster random sampling technique. The sample in the experimental group was 32 students and the control group was 30 students. Data used as a test method in the form of a subjective test (description). The data obtained were analyzed using the t-test analysis technique with the polled variance formula. The results of data analysis were obtained ( $t$ count $=4.021>t$-table $=2,000)$ at the significance level of $5 \%(\mathrm{dk}=32+30-2=67)$ which means that there was a significant difference in the ability to think critically mathematics between groups being taught with the model of Problem Based Learning with media aids Concretely with the group learned using conventional learning models in class IV elementary school. It can be concluded that the Problem Based Learning model assisted by concrete media influences the ability to think critically mathematics in class IV. The results of this study can be used as input for teachers to choose various learning models in teaching.
\end{abstract}

\section{Introduction}

Education is an absolute need and must be fulfilled. This is because education has an important role, without human education it is difficult to develop because education can also affect the level of quality of human resources. This is very important so that humans can face the challenges of every change so that they can compete in the face of the globalization era (Saputra \& Sukmana, 2019). Along with the times, education continues to experience changes from time to time to improve the quality and quality of education (Misla \& Mawardi, 2020). This can be seen from the development of the Indonesian education curriculum (Islamiah et al., 2018). The education curriculum in Indonesia uses the 2013 curriculum. In the 2013 curriculum, it directs students to be able to think at higher levels, namely the ability to think critically. 
Critical thinking skills are useful in a series of process activities to solve problems, make decisions, analyze assumptions, and carry out scientific research (Farisi et al., 2017; Ahmatika, 2017). (Islamiah et al., 2018) argues that critical thinking is a systematic structured procedure that directs students to be able to analyze, formulate, and evaluate information according to their own opinions. With the ability to think critically, students will be successful in life, especially solving problems in everyday life (Winoto \& Prasetyo, 2020). The ability to think critically is always related to mathematics (Luthfiana \& Purwasi, 2018). Mathematics is a science that puts forward-thinking processes and has a good impact on students (Usmiati, 2018). In learning mathematics, it can also provide benefits for learning to reason critically, actively, and creatively (Susanto, 2016). At the basic education level, learning mathematics has a lot of influence on creative thinking and constructing students' new abilities. So, learning mathematics has the goal of making students accustomed to being able to think logically, systematically, and creatively, especially being able to develop their critical thinking skills.

However, in fact, in learning mathematics students are not required to think critically. Even though $21 \mathrm{st}-$ century learning in mathematics subjects, teachers should implement learning strategies with characteristics, among others, (1) student-centered learning, (2) developing student creativity, (3) creating an interesting, fun atmosphere. and meaningful, (4) developing abilities that are loaded with values and meaning, (5) learning through doing (students actively doing), (6) emphasizing exploration, discovery, and creation and (7) creating learning in real situations and actual contexts (Primayanti, 2019) So, the learning carried out should be adapted to the characteristics of the 21 st century and can equip students with critical thinking skills in the context of mathematics (Abad et al., 2018). It is proven that students still find it difficult to understand and develop critical thinking skills with the problems they face daily. It can also be proven that there are students who do not focus when the teacher or other students explain the material or do practice questions in front of the class. Because of this problem, the learning that took place was not entirely successful because it did not focus on students' critical thinking skills.

This is supported by the results of observations and interviews conducted with grade IV teachers at SD Negeri Gugus III Kuta. It can be seen from the critical thinking stage in the context of mathematics, there are $30 \%$ of students who cannot understand a problem, $23 \%$ of students do not plan to solve problems, and $11 \%$ of students do not evaluate the results of the correct answer. Based on the description of the data, it is summarized that there are $66 \%$ of students who cannot think critically in the context of mathematics out of 293 students. Even though the ability to think critically is very useful for the process of solving problems in everyday life within the scope of learning. Besides, in the learning process, innovative learning models and learning support media have not been applied in the context of mathematics. If this is not resolved, students are threatened with not having many alternatives in answering problems, students' emotions become uncontrollable because they are easily manipulated by their friends, and students do not have independence because they are too dependent on others. This can also have an impact on student learning outcomes. From these conditions, it is very clear that students expect a renewal in learning mathematics in class. Therefore, it is necessary to apply other methods or ways that can motivate students to be interested in learning by developing an innovative learning model and learning support media that can improve critical thinking skills and be adapted to the cognitive development of students who are at the concrete operational stage, namely the Problem Based Model. Learning (PBL) is assisted by concrete media.

The Problem Based Learning (PBL) model is a learning model that expects students to work on authentic problems to compile their knowledge, developing inquiry, and higher thinking skills, developing independence, and self-confidence (Sudiatmika et al., 2016). The application of the Problem Based Learning model can be developed through real problems by asking questions submitted by the teacher so that in solving these questions students can get information and develop about topics, compile a problem framework, collect and analyze, compile facts, and opinions about a problem in problem-solving it (Canessia et al., 2019). The Problem Based Learning Model has characteristics, namely a concrete problem in a condition that requires students to learn critically and skillfully solve a problem so that they gain new knowledge (Shoimin, 2017). Characteristics of Problem Based Learning according to Sanjaya (Kodir, 2018) namely (1) Involving students in every learning activity, (2) Learning activities that focus on solving problems, (3) Solving problems using natural thinking. With this model, the teacher must provide stimulation in the form of assignments with various alternative problem-solving methods, as facilitators, and motivators. In addition, this model accustoms students to learning to obtain information and to use this information in solving factual problems faced and then analyzing strategies in problem-solving (Kodir, 2018). (Marian et al., 2016; Luh et al., 2017) This Problem Based Learning model is associated with individual intelligence in a group to solve problems that are meaningful, relevant, and contextual and emphasize student involvement in problem-solving through investigations in solving real problems. Because the Problem Based Learning model of learning requires students to learn actively and critically to carry out investigations in solving problems so that the teacher acts as a facilitator and guides students in the learning process (Dewi, 2017). In the learning process, students are also able to apply their knowledge about what they have obtained and found solutions to problems (Putra, 2017). 
According to (Kodir, 2018) This model also has several advantages, namely (1) by finding concepts independently, students will understand them better, (2) active student involvement in solving problems can improve higher-order thinking skills, (3) learning will be more meaningful because of their basic knowledge. students, (4) provide benefits because problem-solving is directly related to daily life so that student learning motivation can increase, (5) the ability to express and accept aspirations from others results in the growth of an independent nature, (6) organization of learning with a group system can achieve the expected completeness of learning, (7) The existence of active student learning is believed to be able to guide the development of creative abilities in study groups and individually.

This Problem Based Learning model also not only instructs listening to the material, then notes and memorizes it, but emphasizes developing critical thinking skills, digging and studying information, and making a problem conclusion (Lismmaya, 2019). According to Tan (Putri et al., 2019), PBL is an innovation in learning because in PBL the thinking ability of students is optimized through a systematic group or teamwork process so that students can empower, hone, test, and develop their thinking skills on an ongoing basis. In addition to helping students learn difficult concepts, this model also has a function in developing teamwork skills and accustoming students to think critically so that their abilities can increase (Meriani et al., 2017; Saputro et al., 2019). The ability to think critically and student learning outcomes can be improved if the material presented uses innovative methods, such as the PBL model, but using this model alone has not been fully successful because of the need for learning support media that teachers and students must use to find it easier to learn the material. This research is strengthened by research (Rahman et al., 2020) which states that the Problem Based Learning model affects the critical thinking skills of elementary school students in grade V on the heated material and its transfer. In addition, research that supports this research is conducted by (Devi \& Bayu, 2020) which states that learning by applying the PBL model affects the critical thinking skills and learning outcomes of elementary school students. This was obtained through the increase between the pre-test and post-test scores of students who were applied to the PBL model with students who were taught using other models at school.

Besides making it easier, the use of a medium will certainly affect the success of a learning process. Media is a tool for teachers that is used as a means to sharpen students' understanding of the material or explanation presented by the teacher (Ekayani, 2017). Learning media has various types consisting of 4 types, namely visual media, audio media, audio-visual media, and multimedia (Saifuddin, 2018). In addition, some concrete media or media use real objects. A solution to mathematical problems requires media, namely concrete media (Santiani et al., 2017). According to (Dewi et al., 2017) In addition, some concrete media or media use real objects.

A solution to mathematical problems requires media, namely concrete media (Sari et al., 2018) In addition, some concrete media or media use real objects. A solution to mathematical problems requires media, namely concrete media (Aryantha, 2019) stated that after the use of concrete media there was an increase in students' motivation and mathematics learning achievement. Differences in research conducted (Sari et al., 2018) with this research lies in the competence of science knowledge and the research carried out (Aryantha, 2019) what is measured is the increase in motivation and mathematics learning outcomes, while in this study what is measured is the ability to think critically in mathematics. So, in this study, the aim was to determine the significant effect of the Problem Based Learning model with concrete media on the critical thinking skills of fourth-grade students of SD Negeri Gugus III Kuta for the 2019/2020 academic year. This research is expected to provide benefits that have a positive impact in the world of education and become a reference for educational theory, especially in mathematics in developing strategies, methods, and learning models to increase student creativity and knowledge.

The difference between this research and other research lies in the teaching material, research subjects, research locations, and most importantly the learning steps. The learning steps for the Problem Based Learning model are assisted by concrete media, namely (1) the teacher explains the learning objectives. (2) Students are given a real problem by the teacher related to the teaching material. (3) The teacher helps students organize tasks through the problems given. (4) The teacher assists students in finding solutions to problems. (5) The teacher assists students in providing reflection or evaluation during learning activities. Through these learning steps, the most important point lies in the provision of real problems given by teachers assisted by concrete media that can be directly observed by students.

\section{Method}

This type of research design was a quantitative study. The experimental design used two school groups. First, schools that would use the Problem Based Learning learning model assisted by concrete media. Second, schools that would use conventional learning. The experimental design used was the Non-equivalent Control Group Design. The population of this study was the entire class IV SD Negeri Gugus III Kuta for the 2019/2020 academic year, totaling 293 students consisting of 4 schools. According to (Sugiyono, 2019) argues that the population was all generalizations of either object or subject and has characteristics according to the determination 
of the researcher so that it can be further understood to determine the research conclusions. The next step was to determine the sample in the study using random sampling techniques.

By using this technique, the class was randomized. To determine the sample, the method used was a lottery by randomizing the class and not randomizing it individually, the likelihood of students knowing that they were involved in the experiment could be reduced so that this study could affect the treatment given. Then a drawing was carried out by writing all the names of grade IV in each school in SD Negeri Cluster III population on paper, and then rolled it up. Then, put the roll of paper in a glass and shake it. After getting the results of the lottery and two groups were selected as the research sample. Two research samples were obtained from the draw results, namely SDN 1 Tuban and SDN 6 Tuban. The second drawing was conducted to determine the experimental class and the control class, so SDN 1 Tuban was chosen as the experimental class and SDN 6 Tuban as the control class. After that, the group equalization was carried out by giving a pre-test. Data from the pre-test results were analyzed using the t-test. Before the equality test uses the t-test, the pre-test result data was tested for prerequisites, namely the normality and homogeneity tests. If the pre-test results obtained met the prerequisites then analyzed using the t-test using the polled variance formula t-test with the group criteria declared equivalent at the 5\% significance level and $\mathrm{dk}=\mathrm{n} 1+\mathrm{n} 2-2$ on the criteria if $\mathrm{t}$-count $\leq \mathrm{t}$ table so that $\mathrm{H} 0$ received. Conversely, if the group is declared unequal if $\mathrm{t}>\mathrm{t}$ table, then $\mathrm{H} 0$ was rejected.

The data collection method used in this research was the test method. The test method was a method of collecting data through assigning assignments to students and the results are in the form of values to measure students' cognitive (Cahyadi, 2016). The data collected in this study were data on the critical thinking skills of grade IV SD Negeri Gugus III Kuta for the academic year 2019/2020 which was the sample group. The data collection instrument in this study used a subjective form test (description) which consisted of 10 items. Each question contains all 3 indicators of critical thinking skills and was tailored to the material studied by students. The lattice of the instrument is presented in table 1 as follows.

Table 1. Instrument Blue Print

\begin{tabular}{|c|c|c|c|c|c|}
\hline $\begin{array}{l}\text { Core } \\
\text { Competency }\end{array}$ & $\begin{array}{l}\text { Basic } \\
\text { Competency }\end{array}$ & Indicators & $\begin{array}{c}\text { Level of } \\
\text { Difficulty / } \\
\text { Type of } \\
\text { Learning } \\
\text { Outcomes }\end{array}$ & $\begin{array}{c}\text { Number } \\
\text { of } \\
\text { Questions }\end{array}$ & $\begin{array}{l}\text { Critical Thinking } \\
\text { Ability Indicator }\end{array}$ \\
\hline $\begin{array}{l}\text { 3. Understand } \\
\text { factual } \\
\text { knowledge } \\
\text { by observing } \\
\text { listening, } \\
\text { seeing, } \\
\text { reading, and } \\
\text { asking } \\
\text { questions } \\
\text { based } \\
\text { curiosity } \\
\text { about } \\
\text { himself, } \\
\text { God's } \\
\text { creatures and } \\
\text { their } \\
\text { activities, and } \\
\text { the objects he } \\
\text { finds at home } \\
\text { and school. }\end{array}$ & $\begin{array}{l}3.9 \text { Describe } \\
\text { and } \\
\text { determine } \\
\text { the } \\
\text { perimeter } \\
\text { and area of } \\
\text { squares, } \\
\text { rectangles, } \\
\text { and } \\
\text { triangles } \\
\text { and their } \\
\text { square } \\
\text { roots }\end{array}$ & $\begin{array}{l}\text { 3.9.1 Understand } \\
\text { square } \\
\text { numbers and } \\
\text { square roots } \\
\text { 3.9.2 Calculate the } \\
\text { perimeter of a } \\
\text { square, } \\
\text { rectangle, and } \\
\text { triangle shape } \\
\text { 3.9.3 Calculate the } \\
\text { area of a } \\
\text { square, } \\
\text { rectangle, and } \\
\text { triangle shape } \\
\text { 3.9.4 Calculate the } \\
\text { area of the } \\
\text { combined } \\
\text { area (square, } \\
\text { rectangle, and } \\
\text { triangle). }\end{array}$ & C6 & 4 & $\begin{array}{l}\text { 1. Determine } \\
\text { the concept } \\
\text { in problem- } \\
\text { solving } \\
\text { 2. Evaluating } \\
\text { problem- } \\
\text { solving }\end{array}$ \\
\hline
\end{tabular}

Number of Questions

The test that was distributed to students in the experimental and control groups was previously tested to validate the instrument. Instrument testing was done to determine its feasibility by using validity and reliability tests. To measure the validity of the test items for the ability to think critically in mathematics in the form of the description using the product-moment correlation formula because it was politomic. Of the 12 items tested, 10 items were valid and 2 items were invalid. Furthermore, by conducting a reliability test to see the consistency of 
the test items. The reliability test was carried out only on the items that were declared valid. Because it was polyatomic, it used the Alpha Cronbach formula. The items were then given to the experimental and control groups at the end of the study as post-test data. From the results of the post-test data then analyzed.

There were two data analysis methods used, namely descriptive analysis and inferential analysis. Description of the data in this study, namely the amount, average (mean), standard deviation, and variance to test the hypothesis using the t-test with the polled variance formula, beforehand the prerequisite analysis test was carried out consisting of a data distribution normality test and test homogeneity of the variance. This prerequisite test was used to determine whether the data obtained was normal and homogeneous.

\section{Result and Discussion}

The results of the research that have been carried out by giving each treatment as much as 6 times at SDN 1 Tuban as an experimental class by applying the Problem Based Learning model assisted by concrete media and SDN 6 Tuban as a control class applying conventional learning. At the end of the study, a post-test was given to obtain data on critical thinking skills in mathematics. Description of the data in this study, namely the amount, average (mean), standard deviation, and variance. The recapitulation of the results of the description of the data on the critical thinking skills of students in the experimental group and the control group are presented in table 2 as follows.

Table 2. Recapitulation of Results Description of Mathematical Critical Thinking Ability

\begin{tabular}{lcc}
\hline Statistics & $\begin{array}{c}\text { Group } \\
\text { Control }\end{array}$ \\
\hline Total students & $\begin{array}{c}\text { Group } \\
\text { Experiment }\end{array}$ & 30 \\
Average & 32 & 64,17 \\
Standard Deviation & 81,47 & 16,60 \\
Variance & 17,24 & 275,592 \\
Maximum Value & 297,096 & 92 \\
Minimum Value & 100 & 40 \\
\hline
\end{tabular}

Based on table 2, it is found that the post-test mean score of the experimental group is 81.47 and the control group is 64.17. This states that the data on the value of the critical thinking skills of mathematics in the experimental group which were taught through the Problem Based Learning model assisted by concrete media have a higher average than the control group taught using conventional learning.

The data obtained were then carried out by testing the hypothesis using the t-test which previously had to meet the prerequisite tests, namely the normality test of data distribution and the homogeneity test of variance. The data distribution normality test used the Kolmogorov-Smirnov table and the variance homogeneity test used the $\mathrm{F}$ test. The recapitulation of the results of the data distribution normality test and the variance homogeneity test of the critical thinking skills in mathematics is presented in table 3 as follows.

Table 3. Recapitulation of Data Distribution Normality Test Results and Variance Homogeneity Test for Research Samples

\begin{tabular}{lcc}
\hline Statistics & Class Experiment & Class Control \\
\hline $\mathrm{N}$ & 30 & 32 \\
Maximum Value |Ft-Fs| & 0,166 & 0,145 \\
Table Value & 0,234 & 0,242 \\
Kolmogorov-Smirnov & Normally distributed & Normally distributed \\
Conclusion & 297,096 & 275,592 \\
$\mathrm{~S}_{1}{ }^{2}$ & & 29 \\
$\mathrm{~S}_{2}{ }^{2}$ & 31 & \\
Dk & 1,078 & \\
$\mathrm{~F}_{\text {-count }}$ & 1,848 & Homogenous \\
$\mathrm{F}_{\text {-table }}$ & Homogenous \\
\hline Conclusion &
\end{tabular}


Based on the results of calculations in the experimental group, it was found that the maximum value of $\mid \mathrm{Ft}$ - Fs $\mid$ that is 0.166 . Then the value is compared with the Kolmogorov-Smirnov table value for a significance level of $5 \%(\alpha=0.05)$ and $\mathrm{N}=32$, namely 0.234 . Therefore, the maximum value of $|\mathrm{Ft}-\mathrm{Fs}| \leq$ Kolmogorov-Smirnov table value, namely $0.166 \leq 0.234$, then the data distribution of the experimental group is normally distributed. Meanwhile, the calculation results in the control group showed that the maximum value of $|\mathrm{Ft}-\mathrm{Fs}|$ namely 0.145 . Then the value is compared with the Kolmogorov-Smirnov table value for a significance level of 5\% $(\alpha=0.05)$ and $\mathrm{N}=30$, namely 0.242 . Therefore, the maximum value of $|\mathrm{Ft}-\mathrm{Fs}| \leq$ Kolmogorov-Smirnov table value, namely $0.145 \leq 0.242$, then the data distribution of the control group is normally distributed.

The data in the experimental and control groups were normally distributed, so the homogeneity test was then carried out. The homogeneity test is intended to ensure that the differences in the t-test results obtained are true of the differences between groups. The homogeneity test of variance was carried out using the F test (fisher test). Through a significance level of $5 \%$ with degrees of freedom for the numerator $n 1-1$ and degrees of freedom for the denominator $\mathrm{n} 2-1$. With the criteria if Fcount $\leq$ Ftable then the sample is homogeneous and if Fhitug $>$ Ftable then the sample is not homogeneous. Based on the analysis results obtained the value of Fcount $=1.078$. The Ftable with dk numerator $(32-1=31)$ and dk denominator $(30-1=29)$ for the $5 \%$ significance level $(\alpha=0.05)$ is 1,848 . Thus, the value of Fcount <Ftable so that the data of the two groups is stated to have a homogeneous variance. Based on the prerequisite test, the experimental and control group data results were normally distributed and had homogeneous variance. The data collection has met the prerequisite test analysis so that it can perform hypothesis testing using parametric statistical analysis with polled variance t-test. The recapitulation of the t-test results in the two sample groups is presented in table 4 as follows.

Table 4. Recapitulation of t-test analysis results for post-test data

\begin{tabular}{lccccccc}
\hline Sample & Mean & Variants & Dk & $\mathbf{N}$ & t-count & t-table & Conclusion \\
\hline Experiment Group & 81,47 & 297,096 & 60 & 32 & 4,021 & 2,000 & $\mathrm{H}_{0}$ Rejected \\
Control Group & 64,17 & 275,592 & & 30 & & \\
\hline
\end{tabular}

Based on the results of these calculations, the $\mathrm{t}$-test data obtained, namely $\mathrm{t}$-count $=4.021>\mathrm{t}$-table $=2,000$ through a significance level of $5 \%(\alpha=0.05)$ with $\mathrm{dk} 32+30-2=60$ indicating that Ho is rejected. So it was found that there was a significant difference in critical thinking skills between groups of students who were taught through the Problem Based Learning learning model assisted by concrete media and groups of students who were taught through conventional learning in class IV SD Negeri Gugus III Kuta for the 2019/2020 school year. From the results of the t-test analysis which states that there is a difference between the experimental group and the control group in class IV SD Negeri Gugus III Kuta for the 2019/2020 school year, then a test is carried out to determine the effect of the Problem Based Learning model assisted by concrete media by comparing the average value of ability. critical thinking mathematics of both sample groups.

The results showed that the average value of the experimental group's critical thinking ability was 81.47 and the control group's critical thinking ability was 64.17 because it was $81.47>64.17$, so it could be interpreted that the Problem Based Learning model assisted by concrete media affected the ability critical thinking class IV SD Negeri Gugus III Kuta for the 2019/2020 school year. This shows that the average value of the experimental group's critical thinking ability is better than that of the control class. It can be seen from students who take learning using the Problem Based Learning model assisted by concrete media have a higher average than the average students who take conventional learning. This is because in learning activities students feel interested and fun. In addition, it can hone students' reasoning power in dealing with problems related to mathematics subjects.

In this study, applying the Problem Based Learning model students were given various kinds of problems related to mathematics and students thought of answers to these problems to get a solution. Trianto (Abdullah et al., 2015; Kusumawat, 2015) a learning model that is based on the many problems that require authentic investigation, namely investigations that require real solutions to real problems. In addition, using this model has a strong impact on learning because this model helps students to always be active in solving problems in groups or individually. According to (Santiani et al., 2017; Mubarok \& Nanang, 2013) Problem Based Learning (PBL) or problem-based learning is a learning strategy by exposing students to practical problems as a foothold in learning or other words students learning through problems. According to the theory of (Lismaya, 2019), It is believed that the Problem Based Learning model is very appropriate to be used to understand the content of the lesson because students are faced directly with real problems so that learning becomes meaningful for students. This is supported by opinion (Kodir, 2018) who said that the advantages of the Problem Based Learning model assisted by concrete media are 1) students better understand concepts, 2) are actively involved in solving problems, and 3) demand high-order thinking skills. As an effort to support learning media and help in implementing this model, namely by 
using concrete media that can help students better understand the material presented because concrete media is real (real) objects around the student's environment.

According to (Santiani et al., 2017) learning conditions by applying the Problem Based Learning learning model assisted by concrete media appear to be student-centered, where the role of students is more dominant in discussing, solving problems given by the teacher, conducting investigations, and collecting information related to the material being studied and provide the opportunity to apply the knowledge they have to the real world. This theory is comparable with the findings in the field, namely problem-based learning with the help of using concrete media, making student learning activities more enjoyable and students' attention can be distracted to learn. The use of concrete media does not have to be presented in a real way in the classroom but can also invite students to see directly (observation) of real objects to their location (Destrinelli, 2018). By giving problems, students begin to hone their rational powers so that students' skills in thinking critically are formed. That way, students can solve their problems well. Then, students are trained to express the results of their thoughts through a study group discussion. In this activity, the ability of students to express opinions will be honed and make students more confident through discussion by exchanging opinions with their friends.

The findings obtained from this study are that the class that is applied to problem-based learning has a higher learning enthusiasm. Discussion activities between groups become focused because students are focused on discussing a problem given by the teacher. If students have found answers, students will share the results of their discussions with other friends and the teacher. By presenting the results of the discussion, students' communication skills will get better. In addition, they will appreciate it more when there are differences of opinion and understanding of problems from other students. Agree with the theory put forward by (Sari \& Wardani, 2015) Problem-based learning stimulates students to be more participative in learning activities in groups or presentations so that it can create collaboration in groups, besides that students, are more enthusiastic in expressing opinions, through discussion activities of mutual respect between students grow well.

This research is strengthened by relevant research, namely, research conducted by (Purbarani et al., 2018) with the title "The Effect of Audio-Visual Media Assisted Problem Based Learning on Critical Thinking Ability and Science Learning Outcomes in Elementary Schools". With the results showing that the Problem Based Learning model assisted by audio-visual media affects the critical thinking skills and science learning outcomes of class III students based on MANOVA analysis. It is proven that the average score of science learning outcomes of students who take learning with a scientific approach based on Problem Based Learning assisted by audio-visual media is 82.32 in the interval $X>75$. Based on the category calculation results, it can be concluded that the science learning outcomes of students who take learning with a scientific approach based on Problem Based Learning assisted by audio-visual media are in the "Very High" category. The average score of students' critical thinking skills who take learning with a conventional-based scientific approach is 62.44 in the $58<\mathrm{X} \leq 75$ interval. in the "High" category. Research conducted by Christiana, et., al., (2014) states that the project-based Problem Based Learning (PBL) model affects the critical thinking skills of students in class V group VIII, Sukawati sub-district as evidenced by t-count $=2.11>\mathrm{t}$-table $=2,000$ and the average science critical thinking ability test for students in the experimental group 72, 08> 69.92 control group. Based on the results of the study, it can be concluded that the Problem Based Learning model assisted by concrete media affects critical thinking skills. Because using this model causes students to be actively involved in solving problems and can develop high-level skills.

It is common for every teacher to apply the learning model in schools. However, the application of the model if it is not following the characteristics of each school will not run optimally. The application of a learning model must be able to increase students 'willingness to learn, students play an active role, increase student curiosity, and students' thinking power becomes better. If the Problem Based Learning learning model is applied in schools, in addition to students, teachers and school principals also get the impact. Teachers can use this model as a comparison to how teachers teach daily to find out students' critical thinking skills, especially in mathematics, and the principal can use the Problem Based Learning model as a material to add insight and information about innovative learning models. Apart from that, other researchers are also hit by the implications. For other researchers, this research can be used as a reference for the use of innovative learning models with various media.

\section{Conclusion}

Based on the data analysis and discussion, it can be concluded that the Problem Based Learning model assisted by concrete media has an effect on the critical thinking skills of mathematics in grade IV SD Negeri Gugus III Kuta for the academic year 2019/2020 seen from the results of $t$-test analysis with a score of t-count $=4.021$ > $\mathrm{t}$ table 2,000. Problem Based Learning model assisted with concrete media causes students to appear active in solving problems and developing high-level skills. 


\section{References}

Abad, K., Sekolah, D., Pertama, M., Andayani, Y., Sridana, N., Setiadi, D., \& Hadiprayitno, G. (2018). Jurnal Edukasi Sumba ( JES ).

Abdullah, D. I., Mastur, Z., \& Sutarto, H. (2015). Keefektifan model pembelajaran problem based learning bernuansa etnomatematika terhadap kemampuan pemecahan masalah siswa kelas VIII. Unnes Journal of Mathematics Education, 4(3).

Ahmatika, D. (2017). Peningkatan Kemampuan Berpikir Kritis Siswa Dengan Pendekatan Inquiry/Discovery. Euclid, 3(1), 394-403. https://doi.org/10.33603/e.v3i1.324

Aryantha, I. M. (2019). Efektivitas Penggunaan Media Konkret Terhadap Matematika Siswa Kelas III SD. 1-6.

Astuti, S. D. (2017). Untuk memenuhi tuntutan tersebut, guru perlu memahami karaketeristik siswanya. Pentingnya Memahami Karakteristik Siswa Sekolah Dasar Sebagai Dasar Pengembangan Strategi Pembelajaran Oleh Guru, 1-10.

Cahyadi, I. wayan M. (2016). Penerapan Model Tgt Meningkatkan Penguasaan Kompetensi Pengetahuan Ipa Siswa Kelas $\mathrm{Vb}$ Sd Negeri 8 Pemecutan. Mimbar PGSD Undiksha, 4(1), 1-10. https://doi.org/10.23887/jjpgsd.v4i1.7521

Canessia D.Putri, N. M., Ardana, I. K., \& Agustika, G. N. S. (2019). Pengaruh Model Discovery Learning Berbantuan Lingkungan Terhadap Kompetensi Pengetahuan IPA Siswa Kelas V. Mimbar PGSD, 7(2), 5764.

Christiana, P. P., Suniasih, N. W., \& Suadnyana, I. N. (2014). Pengaruh Model Problem Based Learning Berbasis Penilaian Proyek Terhadap Kemampuan Berpikir Kritis Ipa Sd Gugus VIII Sukawati Universitas Pendidikan Ganesha e-Journal Mimbar PGSD Universitas Pendidikan Ganesha.

Devi, P. S., \& Bayu, G. W. (2020). Berpikir Kritis dan Hasil Belajar IPA Melalui Pembelajaran Problem Based Learning Berbantuan Media Visual. MIMBAR PGSD Undiksha, 8(2), 238-252.

Destrinelli, D., Hayati, D. K., \& Sawinty, E. (2018). Pengembangan Media Konkret Pada Pembelajaran Tema Lingkungan Kelas III Sekolah Dasar. Jurnal Gentala Pendidikan Dasar, 3(2), 313-333.

Dewi, N. L. R. A., Ardana, I. K., \& Kristiantari, D. M. R. (2017). Pengaruh Model Pembelajaran Nht Berbantuan Media Konkret Terhadap Kompetensi Pengetahuan Ips Siswa Kelas IV SD Universitas Pendidikan Ganesha. PGSD Universitas Pendidikan Ganesha, 5-2, 1-10.

Dewi, N. M. J. (2017). Pengaruh Model Pembelajaran Problem Based Learning Berbantuan Media Audio Visual Animasi Terhadap Hasil Belajar Ipa. Mimbar PGSD Undiksha, 5(2). https://doi.org/10.23887/jjpgsd.v5i2.10657

Ekayani, P. (2017). (2017). Pentingnya Penggunaan Media. March. https://www.researchgate.net/publication/315105651

Farisi, A., Hamid, A., \& Melvina. (2017). Pengaruh Model Pembelajaran Problem Based Learning terhadap Kemampuan Berpikir Kritis dalam Meningkatkan Hasil Belajar Ssiswa pada Konsep Suhu dan Kalor. Jurnal Ilmiah Mahasiswa, 2(3), 283-287. http://www.jim.unsyiah.ac.id/pendidikan-fisika/article/view/4979

Islamiah, A. F., Rahayu, S., \& Verawati, N. N. S. P. (2018). Efektivitas Model Pembelajaran Problem Based Learning Berbantuan LKS Terhadap Kemampuan Berpikir Kritis Fisika Siswa SMAN 1 Lingsar Tahun Ajaran 2016/2017. Lensa : Jurnal Kependidikan Fisika, 6(1), 29. https://doi.org/10.33394/j-lkf.v6i1.933

Kodir, Abdul. 2018. Manajemen Pembelajaran Saintifik Kurikulum 2013 Pembelajaran Berpusat pada Siswa. Bandung: CV Pustaka Setia.

Kusumawat, W. (2015). Penerapan Model Problem Based Learning Pada Mata Pelajaran IPS Untuk Meningkatkan Hasil Belajar Siswa Kelas Vi SDN Semboro 01 Kecamatan Semboro Kabupaten Jember Tahun Ajaran 2014/2015. Pancaran, 4(4), 1-12.

Lismaya, Lilis. 2019. Berpikir Kritis dan PBL (Problem Based Learning). Surabaya: Media Sahabat Cendeka.

Luh, N., Dianawati, P., Riastini, P. N., \& Pudjawan, K. (2017). Pengaruh Model Pembelajaran Problem Based Learning terhadap Keterampilan Berpikir Kritis IPA Siswa Kelas V SD No . 1 Ungasan Kecamatan Kuta 
Selatan Tahun Pelajaran 2016 / 2017 Sampel penelitian ini dipilih dengan teknik Random Sampling dan diperoleh sampe. 1 .

Luthfiana, M., \& Purwasi, L. A. (2018). Pengaruh Model Pembelajaran Berbasis Masalah terhadap Kemampuan Berpikir Kreatif Matematis. Jurnal Pendidikan Matematika (Judika Education), 1(2), 126-134. https://doi.org/10.31539/judika.v1i2.413

Marian, L. juni, Suwatra, W., \& Gatminah, N. (2016). Pengaruh Model Problem Based Learning Terhadap Hasil Belajar Ipa Siswa Kelas IV Gugus VI. Jurnal PGSD Universitas Pendidikan Ganesha, 4(1), 2.

Meriani, N. K., Darsana, I. W., \& Suardika, I. W. R. (2017). Pengaruh Model Brain Based Learning Berbantuan Media Grafis Terhadap Hasil Belajar Ips Siswa Kelas V SD Negeri Gugus Letda Kajeng Jurusan Pendidikan Guru Sekolah Dasar, FIP Universitas Pendidikan Ganesha. 4.

Misla, \& Mawardi. (2020). Efektifitas PBL dan Problem Solving Siswa SD Ditinjau dari Kemampuan Berpikir Kritis. Jurnal Ilmiah Sekolah Dasar, 4(1), 64-69.

Mubarok, D. M., \& Nanang, N. (2013). Perbedaan Kemampuan Pemecahan Masalah Matematik Antar Siswa yang Mendapatkan Pembelajaran Problem Based Learning (Pbl) dan Jigsaw. Mosharafa: Jurnal Pendidikan Matematika, 2(1), 1-12.

Primayanti, P. E., Suarjana, I. M., \& Astawan, I. G. (2019). Pengaruh Model Pbl Bermuatan Kearifan Lokal terhadap Sikap Sosial dan Kemampuan Berpikir Kritis Matematika Siswa Kelas V di Gugus V Kecamatan Sukasada. Thinking Skills and Creativity Journal, 1(2), 86. https://doi.org/10.23887/tscj.v1i2.20417

Purbarani, D. A., Dantes, N., \& Adnyana, P. B. (2018). Pengaruh Problem Based Learning Berbantuan Media Audio Visual Terhadap Kemampuan Berpikir Kritis Dan Hasil Belajar Ipa Di Sekolah Dasar. PENDASI: Jurnal Pendidikan Dasar Indonesia, 2(1), 24-34. https://doi.org/10.23887/jpdi.v2i1.2689

Putra, I. P. A. S. (2017). Pengaruh Teori Konstruktvisme Model Pembelajaran Problem Based Learning (PBL) Berbantuan Media Gambar Sumber Daya Alam Untuk Pengaruh Model Pembelajaran Problem Based Learning Untuk Meningkatkan Hasil Belajar IPA Siswa Kelas V SD. Mimbar PGSD, 5(2), 2. https://ejournal.undiksha.ac.id/index.php/JJPGSD/article/view/10843/6945

Rahman, A., Khaeruddin, K., \& Ristiana, E. (2020). Pengaruh Model PBL Terhadap Kemampuan Berpikir Kritis dan Pemahaman Konsep IPA Siswa Kelas V SDN 30 Sumpangbita. Edumaspul: Jurnal Pendidikan, 4(1), $29-41$.

Saifuddin. 2018. Pengelolaan pembelajaran teoritis dan praktis. Yogyakarta: deepublish

Santiani, N. W., Sudana, D. N., \& Tastra, I. D. K. (2017). Pengaruh Model PBL Berbantuan Media Konkret terhadap Hasil Belajar IPA Siswa Kelas V SD. E-Journal PGSD Universitas Pendidikan Ganesha, 5(2), 111 .

Saputra, W. F. A., \& Sukmana, A. I. W. I. Y. (2019). Pengaruh Model Pembelajaran Problem Based Learning Berorientasi Tri Hita Karana Terhadap Hasil Belajar Ipa Siswa Kelas V. Jurnal Pendidikan Multikultural Indonesia, 1(2), 51. https://doi.org/10.23887/jpmu.v1i2.20771

Saputro, B., Sulasmono, B. S., \& Widyanti, E. (2019). Belajar Matematika Menggunakan Model Pbl Pada Siswa Kelas V. 3, 621-631.

Sari, D. T., \& Wardani, D. K. (2015). Penerapan Model Pbl Untuk Meningkatkan Kemampuan Berpikir Kritis Dan Hasil Belajar Siswa Pada Materi. November.

Sari, K. A. D. R., Ngurah Wiyasa, K., \& Ganing, N. N. (2018). Pengaruh Model Pembelajaran Inkuiri Terbimbing Berbantuan Media Konkret Terhadap Kompetensi Pengetahuan Ipa. Mimbar Ilmu, 23(2), 104-112. https://doi.org/10.23887/mi.v23i2.16416

Shoimin, A. 2017. 68 Model Pembelajaran Inovatif dalam Kurikulum 2013. Yogyakarta: Ar-Ruzz Media.

Sudiatmika, I. M. A., Subagia, I. W., \& Muderawan, I. W. (2016). Pengaruh Penggunaan Multimedia Pada Model Problem Based Learning (PBL) Terhadap Hasil Belajar Kimia Siswa. Prosiding Seminar Nasional MIPA 2016, 172-178.

Sugiyono. 2019. Statistika Untuk Penelitian. Bandung: Alfabeta.

Susanto, Ahmad. 2019. Teori Belajar dan Pembelajaran di Sekolah Dasar. Jakarta: Prenadamedia Group 
Usmiati A, D. (2018). Pengaruh Model Pembelajaran Probing-Prompting Terhadap Kemampuan Berpikir Kreatif Matematis dan Self Efficacy Siswa SMK Sentosa Buay Madang. Prosiding Seminar Nasional, 508-514.

Winoto, Y. C., \& Prasetyo, T. (2020). Efektivitas Model Problem Based Learning Dan Discovery Learning Terhadap Kemampuan Berpikir Kritis Siswa Sekolah Dasar. Jurnal Basicedu, 4(2), 228-238. https://doi.org/10.31004/basicedu.v4i2.348

Putri, R. S., Suryani, M., \& Jufri, L. H. (2019). Pengaruh Penerapan Model Problem Based Learning terhadap Kemampuan Pemecahan Masalah Matematika Siswa. Mosharafa: Jurnal Pendidikan Matematika, 8(2), 331-340. 